Check for updates

Cite this: Chem. Sci., 2019, 10, 9351

๑ All publication charges for this article have been paid for by the Royal Society of Chemistry

\section{Tumor-acidity activated surface charge conversion of two-photon fluorescent nanoprobe for enhanced cellular uptake and targeted imaging of intracellular hydrogen peroxide $\uparrow$}

\author{
Lanlan Chen, ${ }^{\text {abc }}$ Shuai $\mathrm{Xu}^{\mathrm{c}}{ }^{\mathrm{c}}$ Wei Li, ${ }^{\mathrm{c}}$ Tianbing Ren, (D) ${ }^{\mathrm{c}}$ Lin Yuan, (D) ${ }^{\mathrm{c}}$ \\ Shusheng Zhang $\mathbb{D}^{* a}$ and Xiao-Bing Zhang $(\mathbb{D}$ *c
}

\begin{abstract}
Elevated levels of intracellular hydrogen peroxide $\left(\mathrm{H}_{2} \mathrm{O}_{2}\right)$ are closely related to the development of cancers. Specific imaging of $\mathrm{H}_{2} \mathrm{O}_{2}$ in tumor sites would be significant not only for cancer diagnosis but also for gaining a deep understanding of the role of $\mathrm{H}_{2} \mathrm{O}_{2}$ in cancer. However, traditional fluorescent probes based only on responses to overexpression levels of $\mathrm{H}_{2} \mathrm{O}_{2}$ in cancer cells are insufficient to distinguish cancer cells from other unhealthy or healthy cells in complex biological systems. Herein, we developed a smart, two-photon fluorescent GC-NABP nanoprobe with $\mathrm{pH}$-dependent surface charge conversion for tumor-targeted imaging of $\mathrm{H}_{2} \mathrm{O}_{2}$. The nanoprobe was constructed by the self-assembly of amphiphilic GC-NABP, which was synthesized by grafting the hydrophobic, $\mathrm{H}_{2} \mathrm{O}_{2}$-responsive and twophoton fluorophore, NABP, onto hydrophilic biopolymer glycol chitosan (GC). Taking advantage of $\mathrm{pH}$ titratable amino groups on GC, the nanoprobe had the capability of surface charge conversion from negative at physiologic $\mathrm{pH}$ to positive in the acidic tumor microenvironment. The positive charge of the nanoprobe promoted electrostatic interactions with cell membranes, leading to enhanced cellular uptake in acidic environment. Upon cellular uptake, the high level of $\mathrm{H}_{2} \mathrm{O}_{2}$ in tumor cells triggered boronate deprotections of the nanoprobe, generating a "turn-on" fluorescence emission for $\mathrm{H}_{2} \mathrm{O}_{2}$ imaging. The nanoprobe exhibited good sensitivity and selectivity to $\mathrm{H}_{2} \mathrm{O}_{2}$ with a detection limit down to $110 \mathrm{nM}$ in vitro. The results from flow cytometry and two-photon fluorescence imaging of $\mathrm{H}_{2} \mathrm{O}_{2}$ in living cells and tissues evidenced the enhanced cellular uptake and targeted imaging of intracellular $\mathrm{H}_{2} \mathrm{O}_{2}$ in acidic environment. Compared to control nanoparticles that lack pH sensitivity, our nanoprobe showed enhanced accumulation in tumor sites and was applied to targeted imaging of $\mathrm{H}_{2} \mathrm{O}_{2}$ in a tumor-bearing mouse model. This work demonstrates that the nanoprobe GC-NABP holds great promise for tumorspecific imaging of cellular $\mathrm{H}_{2} \mathrm{O}_{2}$, providing a potential tool to explore the role of $\mathrm{H}_{2} \mathrm{O}_{2}$ in tumor sites.
\end{abstract}

Received 31st July 2019

Accepted 13th August 2019

DOI: $10.1039 / \mathrm{c} 9 \mathrm{sc} 03781 \mathrm{k}$

rsc.li/chemical-science of enzymes, and mediating inflammation. ${ }^{\mathbf{1 , 2}}$ Overproduction and accumulation of $\mathrm{H}_{2} \mathrm{O}_{2}$ cause oxidative stress and can damage cellular proteins, lipids and DNA. ${ }^{3}$ Mounting evidence suggests that abnormal levels of $\mathrm{H}_{2} \mathrm{O}_{2}$ are related to cancers. ${ }^{4-6}$ Elevated generation rates of $\mathrm{H}_{2} \mathrm{O}_{2}$ have also been found in most types of cancer cells (up to $0.5 \mathrm{nmol} / 10^{4}$ cells per $\mathrm{h}$ ). ${ }^{7}$ Therefore, developing effective methods for sensitive detection and realtime monitoring of $\mathrm{H}_{2} \mathrm{O}_{2}$ in tumor sites would be of great significance and highly desirable not only for cancer diagnosis but also for gaining a better understanding of the roles of $\mathrm{H}_{2} \mathrm{O}_{2}$ in the development of cancers.

Fluorescence imaging, particularly using two-photon microscopy (TPM), provides a powerful tool for selective, noninvasive and real-time monitoring of ROS in biological systems with high spatial resolution, deep tissue penetration and low phototoxicity. ${ }^{8-21}$ To date, several two-photon fluorescence probes have been reported for imaging $\mathrm{H}_{2} \mathrm{O}_{2}$ in living
${ }^{a}$ Collaborative Innovation Center of Tumor Marker Detection Technology, Equipment and Diagnosis-Therapy Integration in Universities of Shandong, Shandong Provincial Key Laboratory of Detection Technology for Tumor Markers, College of R. China. E-mail: lanlanchen1989@126.com; shushzhang@126.com

${ }^{b}$ The Key Lab of Analysis and Detection Technology for Food Safety of the MOE, College of Chemistry, Fuzhou University, Fuzhou 350002, P. R. China

${ }^{c}$ State Key Laboratory of Chemo/Biosensing and Chemometrics, Molecular Science and Biomedicine Laboratory, College of Chemistry and Chemical Engineering, Hunan University, Changsha 410082, P. R. China.E-mail: xbzhang@hnu.edu.cn

$\dagger$ Electronic supplementary information (ESI) available. See DOI: $10.1039 / \mathrm{c} 9 \mathrm{sc} 03781 \mathrm{k}$ 
cells and tissues. ${ }^{22-25}$ The "turn on" fluorescence of these probes mainly arises from the oxidative reaction or oxidative rearrangement of the reaction site upon exposure to $\mathrm{H}_{2} \mathrm{O}_{2}$. However, some challenges associated with these fluorescent probes remain for the specific imaging of $\mathrm{H}_{2} \mathrm{O}_{2}$ in tumor sites. First, differentiating tumor tissues and healthy tissues only using responses of fluorescence signals to overexpressed levels of $\mathrm{H}_{2} \mathrm{O}_{2}$ is still insufficient, because the sensitivity of a single response process or event even at a molecular level is limited in a complex biological system. Second, abnormal levels of $\mathrm{H}_{2} \mathrm{O}_{2}$ may also be present in some other unhealthy cells, such as inflamed cells, ${ }^{26}$ increasing the difficulty to effectively distinguish them from cancer cells. Moreover, these small-molecule fluorescent probes often have poor water solubility, biodistribution, rapid renal clearance and short blood circulation, limiting their application to imaging in vivo.

The tumor microenvironment has some unique characteristics; for example, the extracellular $\mathrm{pH}(\mathrm{pHe})$ in solid tumors tends to be more acidic ( $\sim 6.5)$ than that of normal tissues (7.4), on the basis of Warburg effect, where increased metabolism and activated anaerobic glycolysis lead to augmented production of acidic metabolites (e.g., lactate). ${ }^{27-30}$ Many efforts have been devoted to constructing nanomaterials that can respond to this altered acidic tumor microenvironment signal by changing their physicochemical properties including size, zeta potential, and hydrophilic-hydrophobic balance, thereby leading to improved diffusion, cellular uptake, enhanced permeability and retention (EPR) effect and/or targeted imaging. ${ }^{31-38}$ Targeting to an acidic tumor microenvironment provides a generalizable strategy that can be applied to a broad range of tumors compared with other targeting strategies, such as receptorspecific targeting. Inspired by these, constructing a smart nanoprobe via the integration of stimuli-responsive nanomaterials and fluorescent probes with the remarkable tumortargeting capacity of nanomaterials in the acidic tumor microenvironment and the outstanding $\mathrm{H}_{2} \mathrm{O}_{2}$ imaging properties of fluorescent probes, might be a promising way to realize precise tumor-targeted imaging of $\mathrm{H}_{2} \mathrm{O}_{2}$ in vivo.

In this work, we developed a novel, smart, two-photon fluorescent GC-NABP nanoprobe with $\mathrm{pH}$-dependent surface charge conversion for tumor-targeted visualization of $\mathrm{H}_{2} \mathrm{O}_{2}$ (Scheme 1). GC-NABP was constructed by covalently conjugating the hydrophobic, $\mathrm{H}_{2} \mathrm{O}_{2}$-responsive and two-photon fluorophore, NABP, onto side chains of glycol chitosan (GC), which is a water-soluble, low-cost, biocompatible and biodegradable polymer with the capability of pH-titratable charge. ${ }^{39-44}$ GC-NABP exhibited an amphiphilic feature and could self-assemble into nanosized micelles in aqueous solution. Notably, taking advantage of $\mathrm{pH}$ titratable amino groups on $\mathrm{GC}\left(\mathrm{p} K_{\mathrm{a}} \sim 6.5\right)$, the surface charge of the nanoprobe could transition from negative at physiologic $\mathrm{pH}$ to positive in the acidic tumor microenvironment. The nanoprobe with positive charge promoted electrostatic interactions with surrounding cells, leading to enhanced cellular uptake in acidic environment. Once the nanoprobe was internalized in the cells, the high level of $\mathrm{H}_{2} \mathrm{O}_{2}$ in tumor cells could initiate boronate deprotections of the nanoprobe, yielding a "turn-on" fluorescence emission for $\mathrm{H}_{2} \mathrm{O}_{2}$ imaging. The nanoprobe

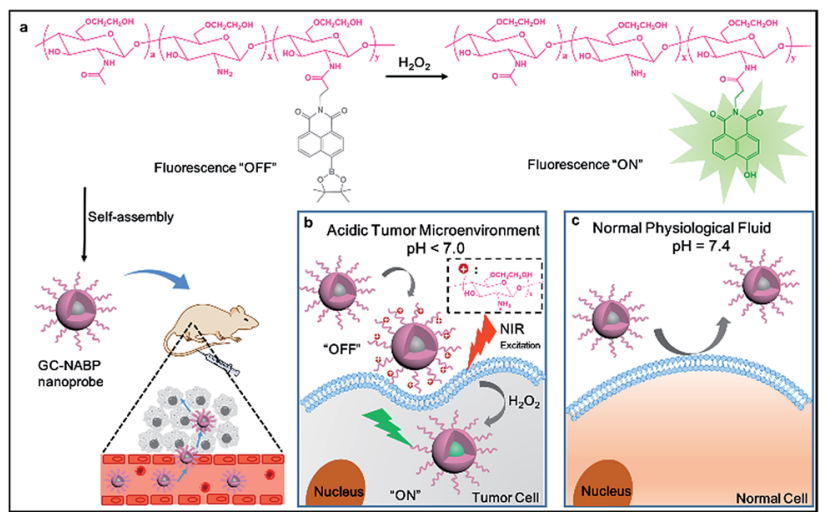

Scheme 1 (a) The "turn on" fluorescence of GC-NABP in the presence of $\mathrm{H}_{2} \mathrm{O}_{2}$ and a schematic illustration of the self-assembled $\mathrm{GC}-\mathrm{NABP}$ nanoprobe for targeted imaging in vivo. (b) Targeted imaging of $\mathrm{H}_{2} \mathrm{O}_{2}$ in a tumor cell with the GC-NABP nanoprobe in an acidic tumor microenvironment. (c) Scheme of GC-NABP nanoprobe in normal physiological fluids.

displayed good sensitivity (a limit of detection of $110 \mathrm{nM}$ in vitro) and selectivity to $\mathrm{H}_{2} \mathrm{O}_{2}$. We investigated the capability of the nanoprobe for promoted cellular uptake and targeted imaging of $\mathrm{H}_{2} \mathrm{O}_{2}$ in living cells and tissues under acidic environment using flow cytometry and two-photon fluorescence imaging. Compared to control nanoparticles that lack $\mathrm{pH}$ sensitivity, the nanoprobe showed enhanced accumulation in tumor sites. Experiments of intravenously injecting the nanoprobe into tumor-bearing mice confirmed that the nanoprobe could achieve tumor-targeted imaging of $\mathrm{H}_{2} \mathrm{O}_{2}$. Our results suggest that the nanoprobe GCNABP might offer a potential imaging tool for tumor-specific visualization of $\mathrm{H}_{2} \mathrm{O}_{2}$.

\section{Results and discussion}

\section{Synthesis and characterization of GC-NABP and the self- assembled nanoprobe}

To construct the GC-NABP nanoprobe for $\mathrm{H}_{2} \mathrm{O}_{2}$ detection, the $\mathrm{H}_{2} \mathrm{O}_{2}$-responsive, two-photon fluorophore, NABP, was synthesized first. As shown in Fig. S1a, $\uparrow$ molecule 1 was synthesized by Suzuki coupling of 4-bromo-1,8-naphthalic anhydride and bis(pinacolato)diboron. NABP was obtained by the treatment of 1 with $\gamma$-aminobutyic acid. The chemical structure of NABP was confirmed by ${ }^{1} \mathrm{H}$ NMR (Fig. S2 $\dagger$ ), ${ }^{13} \mathrm{C}$ NMR (Fig. S3 $\dagger$ ) and HR-MS (Fig. S4 $\dagger$ ). Then, NABP was reacted with primary amine groups of GC to produce GC-NABP in the presence of EDC and NHS (Fig. S1b $\dagger$ ). Compared with the ${ }^{1} \mathrm{H}$ NMR spectrum of GC, new signals of boronate methyl protons at $1.5 \mathrm{ppm}$ and aromatic protons at 8.2-9.0 ppm appeared in the spectrum of GC-NABP (Fig. 1a), suggesting the successful grafting of NABP onto GC. FTIR spectra also confirmed the formation of amide linkages between the carboxyl group of NABP and amine groups of GC (Fig. 1b). Compared with the FTIR spectrum of GC, the peak at $1598 \mathrm{~cm}^{-1}$ in the spectrum of GC-NABP assigned to the $\mathrm{N}-\mathrm{H}$ bending of primary amine significantly weakened. The characteristic peaks at 1658 and $1540 \mathrm{~cm}^{-1}$, attributed to the carbonyl 

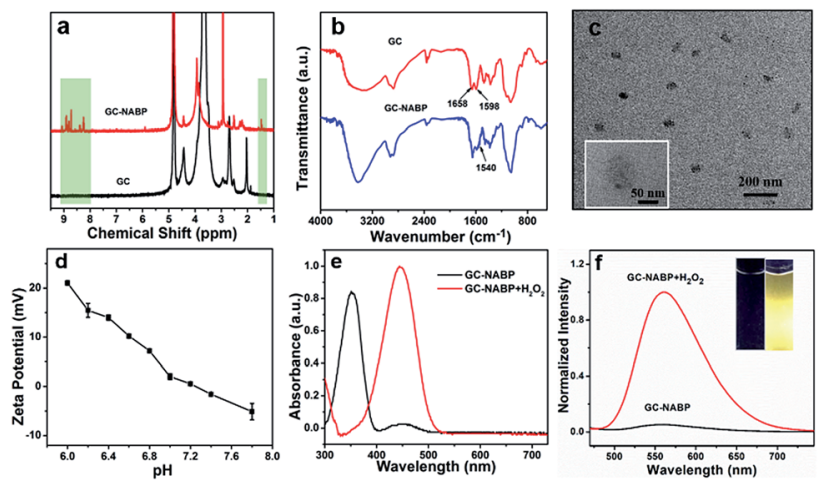

Fig. 1 (a) ${ }^{1} \mathrm{H}$ NMR spectra of $\mathrm{GC}$ in $\mathrm{D}_{2} \mathrm{O}$ and $\mathrm{GC}-\mathrm{NABP}$ in $\mathrm{D}_{2} \mathrm{O} / \mathrm{DMSO}-$ $d_{6}$. (b) FTIR spectra of GC and GC-NABP. (c) TEM image of GC-NABP nanoprobe. Inset: TEM image with high magnification. (d) Zeta potential of $\mathrm{GC}-\mathrm{NABP}$ nanoprobe in buffers with $\mathrm{pH}$ values ranging from 6.0 to 7.8. (e) UV-vis spectra of GC-NABP nanoprobe $\left(200 \mu \mathrm{g} \mathrm{mL}^{-1}\right)$ with and without treatment with $200 \mu \mathrm{M} \mathrm{H}_{2} \mathrm{O}_{2}$ at $37^{\circ} \mathrm{C}$ for 30 min. (f) Fluorescence spectra of GC-NABP nanoprobe with and without treatment with $200 \mu \mathrm{M} \mathrm{H}_{2} \mathrm{O}_{2}$. Inset images show $\mathrm{GC}-\mathrm{NABP}$ nanoprobe solutions in the absence and presence of $\mathrm{H}_{2} \mathrm{O}_{2}$ under UV light at $365 \mathrm{~nm}$.

of amide I band and $\mathrm{N}-\mathrm{H}$ bending of amide II band, respectively, increased after conjugation. The grafting ratio $\left(n_{\mathrm{NABP}}\right.$

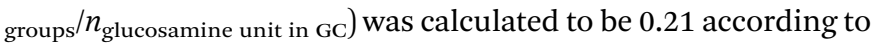
the UV-vis absorbance at $350 \mathrm{~nm}$ of GC-NABP (Fig. S5 $\dagger$ ).

Due to the amphiphilic structure comprising hydrophobic NABP groups and the hydrophilic GC backbone, GC-NABP could be self-assembled into nanosized micelles. The GC-NABP nanoprobe was obtained via a dialysis method. The TEM image (Fig. 1c) shows that the average diameter of the GC-NABP nanoprobe was about $70 \mathrm{~nm}$. DLS results revealed that the nanoprobe had a mean hydrodynamic diameter of $90 \pm 20 \mathrm{~nm}$ in pH 7.4 PBS and the self-assembled nanoparticles remained at acidic pH (Fig. S6a†). The stability of the nanoprobe was also examined under dilute conditions and in biological media. As shown in Fig. S6b, $\uparrow$ the nanoprobe was stable after dilution or in $10 \%$ FBS for $24 \mathrm{~h}$.

\section{Titratability of the nanoprobe surface charge}

To investigate the titratability of the GC-NABP nanoprobe surface charge, the zeta potential of the GC-NABP nanoprobe was measured at different $\mathrm{pH}$ values from 6.0 to 7.8. As shown in Fig. 1d, the GC-NABP nanoprobe demonstrated a distinctly pH-dependent surface charge, with zeta potential values increasing from $-1.58 \mathrm{mV}$ at $\mathrm{pH} 7.4$ to $+21.03 \mathrm{mV}$ upon exposure to $\mathrm{pH} 6.0$ buffer solution. This result suggests that the nanoprobe might be capable of enhanced cellular internalization through electrostatic interactions (between the positively charged nanoprobe and negatively charged cell membranes) that occur preferentially in the acidic tumor microenvironment.

\section{Optical properties of GC-NABP nanoprobe and responses to hydrogen peroxide}

We investigated the optical properties and $\mathrm{H}_{2} \mathrm{O}_{2}$ responses of the GC-NABP nanoprobe in PBS buffer (10 mM, pH 7.4). GC-
NABP exhibited a maximum UV-vis absorption at $350 \mathrm{~nm}$ and weak fluorescence with a maximum at $550 \mathrm{~nm}$. Addition of excess $\mathrm{H}_{2} \mathrm{O}_{2}$ triggered a redshift of the absorbance peak from 350 to $450 \mathrm{~nm}$ and a significant increase in the fluorescence intensity at $560 \mathrm{~nm}$ (Fig. 1e and f). The fluorescence kinetics curve revealed that the fluorescence intensity increased rapidly within 1200 seconds and tended to reach equilibrium at about 3600 seconds when the GC-NABP nanoprobe was treated with a large excess of $\mathrm{H}_{2} \mathrm{O}_{2}(10 \mathrm{mM})$ (Fig. S7a $\dagger$ ). The kinetics curves were fitted with a pseudo-first-order kinetic equation, giving an observed rate constant $\left(k_{\text {obs }}\right)$ of $8.21 \pm 1.43 \times 10^{-4} \mathrm{~s}^{-1}$, which is comparable to those of small molecule probes containing boronic ester moieties for $\mathrm{H}_{2} \mathrm{O}_{2}$ response. ${ }^{45}$

Then, we performed fluorescence titrations of the GC-NABP nanoprobe upon the addition of $\mathrm{H}_{2} \mathrm{O}_{2}$. The fluorescence intensity of the nanoprobe increased gradually with increasing concentration of $\mathrm{H}_{2} \mathrm{O}_{2}$ and reached a plateau at a $\mathrm{H}_{2} \mathrm{O}_{2}$ concentration of $100 \mu \mathrm{M}$ with a $\sim 15$-fold increase (Fig. 2a and b). The nanoprobe exhibited a linear fluorescence response in the low concentration range of $\mathrm{H}_{2} \mathrm{O}_{2}$ with the detection limit down to $110 \mathrm{nM}$ in vitro. Fluorescence responses of the nanoprobe to other biologically relevant reactive oxygen species (ROS), including tert-butyl hyperoxide (TBHP), $\mathrm{OCl}^{-}, \mathrm{O}_{2}{ }^{-},{ }^{\cdot} \mathrm{OH}$, 'OtBu and NO, were also studied. Generally, when treated with $\mathrm{H}_{2} \mathrm{O}_{2}$, the aryl boronate group of the nanoprobe initially reacted as an electrophile in a reversible manner with nucleophiles to form a negatively charged tetrahedral boronate complex; then the $\mathrm{C}-\mathrm{B}$ bond became capable of reacting as a nucleophile
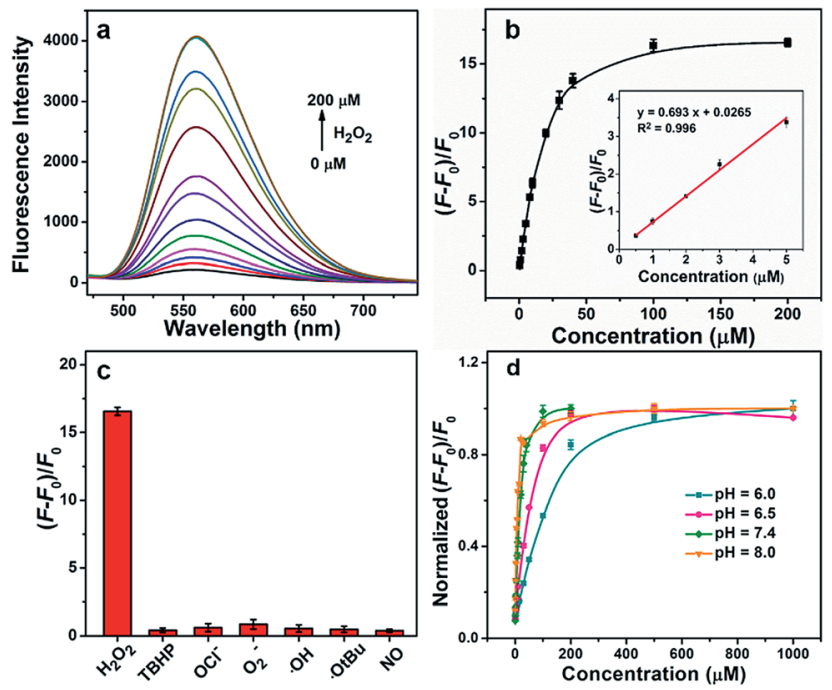

Fig. 2 (a) Fluorescence spectra of the GC-NABP nanoprobe $(20 \mu \mathrm{g}$ $\left.\mathrm{mL}^{-1}\right)$ incubated with different concentrations $(0,0.5,1,2,3,5,8,10$, $20,30,40,100,200 \mu \mathrm{M}$ ) of $\mathrm{H}_{2} \mathrm{O}_{2}$ for 30 min in buffer (10 mM PBS, pH 7.4). (b) Fluorescence response $\left[\left(F-F_{0}\right) / F_{0}\right]$ of GC-NABP nanoprobe at $560 \mathrm{~nm}$ as a function of concentration of $\mathrm{H}_{2} \mathrm{O}_{2}$. Inset: linear relationship of fluorescence response and $\mathrm{H}_{2} \mathrm{O}_{2}$ concentration in the low concentration range. (c) Fluorescence response $\left[\left(F-F_{0}\right) / F_{0}\right]$ of $G C-$ $\mathrm{NABP}$ nanoprobe to various reactive oxygen species $\left(10 \mathrm{mM} \mathrm{O}_{2}{ }^{-}, 200\right.$ $\mu \mathrm{M} \mathrm{NO}$ and $100 \mu \mathrm{M}$ for others). (d) Effect of buffer $\mathrm{pH}$ on fluorescence response $\left[\left(F-F_{0}\right) / F_{0}\right]$ of $G C-N A B P$ nanoprobe to different concentrations of $\mathrm{H}_{2} \mathrm{O}_{2}$. 
(Fig. S8a†). ${ }^{46,47}$ Benefiting from the dual-mode reactivity of $\mathrm{H}_{2} \mathrm{O}_{2}$ with boronate, the nanoprobe displayed a high selectivity for $\mathrm{H}_{2} \mathrm{O}_{2}$ over the other ROS (Fig. 2c), whereas most of the other ROS operated by single-electron transfers or purely electrophilic oxidation pathways. ${ }^{45}$

The $\mathrm{H}_{2} \mathrm{O}_{2}$-triggered "turn-on" fluorescence arises from the deprotection of the phenylboronic acid pinacol ester group on the nanoprobe (Fig. $\mathrm{S} 8 \mathrm{~b} \dagger$ ). The deprotection reaction is irreversible, as shown in Fig. $\mathrm{S9} . \dagger$ With the addition of the reductant, a negligible change of fluorescence intensity was observed. To verify the response mechanism, we investigated the reaction mixture of NABP with $\mathrm{H}_{2} \mathrm{O}_{2}$ using HPLC. As shown in Fig. S10, $\dagger$ with the addition of $\mathrm{H}_{2} \mathrm{O}_{2}$, a new peak at $10.6 \mathrm{~min}$ appeared, corresponding to 4-hydroxy-1,8-naphthalimide fluorophore $(\mathrm{NAOH})$. The strong peak at $m / z 298.02$ (Fig. S11†) was attributed to the $[\mathrm{M}-\mathrm{H}]^{1-}$ ion of $\mathrm{NAOH}$, confirming the oxidation of the boronic ester group to generate $\mathrm{NAOH}$.

The $\mathrm{pH}$ of the reaction solution has an effect on the rate of boronate oxidation; thus, responses of the nanoprobe to $\mathrm{H}_{2} \mathrm{O}_{2}$ at different $\mathrm{pH}$ levels were investigated. As shown in Fig. 2d, due to the promotion of the nucleophilic reaction, the $\mathrm{H}_{2} \mathrm{O}_{2}$ response of the nanoprobe was accelerated at high $\mathrm{pH}$ values. It is worth noting that the nanoprobe could achieve $\mathrm{a}_{2} \mathrm{O}_{2}$ response both at physiological $\mathrm{pH}$ values (e.g. $\mathrm{pH}$ 7.4) and acidic tumor $\mathrm{pH}$ values.

The two-photon fluorescence properties of GC-NABP in the absence and presence of $\mathrm{H}_{2} \mathrm{O}_{2}$ were then studied. GC-NABP treated with $\mathrm{H}_{2} \mathrm{O}_{2}$ exhibited the largest two-photon absorption cross section at $780 \mathrm{~nm}$, whereas that of GC-NABP was very low (Fig. S12†).

Enhanced cellular uptake and targeted fluorescence imaging of hydrogen peroxide in living cells under acidic microenvironment

Encouraged by the good sensitivity and selectivity of the GCNABP nanoprobe for $\mathrm{H}_{2} \mathrm{O}_{2}$ responses, we applied the nanoprobe to $\mathrm{H}_{2} \mathrm{O}_{2}$ imaging in living cells. Before the bioimaging application, cytotoxicity of the nanoprobe was evaluated by MTT assay. The cell viability was about $97 \%$ when cells were incubated with $100 \mu \mathrm{g} \mathrm{mL} \mathrm{m}^{-1} \mathrm{GC}-\mathrm{NABP}$ for $24 \mathrm{~h}$, and remained over $88 \%$ even with the concentration up to $1000 \mu \mathrm{g} \mathrm{mL}$ (Fig. S13†), suggesting that the nanoprobe has negligible cytotoxicity and excellent biocompatibility.

To demonstrate that the GC-NABP nanoprobe has the ability of targeted bioimaging in acidic microenvironment, TPM imaging of $\mathrm{H}_{2} \mathrm{O}_{2}$ in HepG2 cells with the nanoprobe was investigated at two different $\mathrm{pH}$ values, $\mathrm{pH} 7.4$ and 6.5 (Fig. 3). Lipopolysaccharide (LPS) was used to stimulate HepG2 cells to generate endogenous $\mathrm{H}_{2} \mathrm{O}_{2} \cdot{ }^{48}$ Both at $\mathrm{pH} 7.4$ and 6.5, compared with the weak fluorescence observed in HepG2 cells incubated with only the nanoprobe (Fig. 3b and f), cells pretreated with LPS showed increased fluorescence, suggesting that the nanoprobe could image endogenous $\mathrm{H}_{2} \mathrm{O}_{2}$ in living cells. Cells treated with extra $\mathrm{H}_{2} \mathrm{O}_{2}$ also showed obvious fluorescence. Furthermore, cells incubated with the nanoprobe in culture medium at pH 6.5 exhibited brighter fluorescence compared with those incubated at $\mathrm{pH} 7.4$ (Fig. 3i). The nanoprobe was also

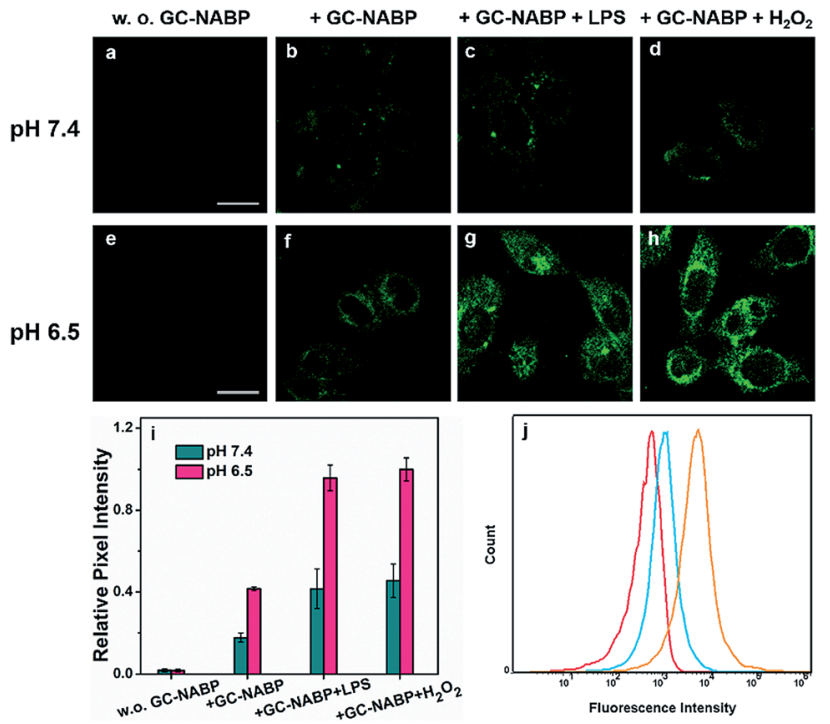

Fig. $3(a-h)$ TPM images of HepG2 cells incubated at two different $\mathrm{pH}$ values. Control images of HepG2 cells treated without the GC-NABP nanoprobe at $\mathrm{pH} 7.4$ (a) and $\mathrm{pH} 6.5$ (e). HepG2 cells treated with only the GC-NABP nanoprobe at $\mathrm{pH} 7.4$ (b) and $\mathrm{pH} 6.5$ (f). HepG2 cells stimulated with LPS and then treated with the GC-NABP nanoprobe at $\mathrm{pH} 7.4$ (c) and pH 6.5 (g). HepG2 cells treated with the GC-NABP nanoprobe and $\mathrm{H}_{2} \mathrm{O}_{2}$ at $\mathrm{pH} 7.4$ (d) and $\mathrm{pH} 6.5$ (h). (i) Relative pixel fluorescence intensity of HepG2 images. (j) Flow cytometry of Hela cells incubated with the GC-NABP nanoprobe at different $\mathrm{pH}$ values for $4 \mathrm{~h}$, and then treated with $\mathrm{H}_{2} \mathrm{O}_{2}$. Red: control; blue: $\mathrm{pH}$ 7.4; orange: pH 6.5. Scale bar: $20 \mu \mathrm{m}$.

applied for $\mathrm{H}_{2} \mathrm{O}_{2}$ imaging in inflamed cells (Fig. S14 $\dagger$ ). At physiological $\mathrm{pH}(\sim 7.4)$, RAW264.7 cells also exhibited negligible fluorescence even when treated with LPS or $\mathrm{H}_{2} \mathrm{O}_{2}$, further confirming that the nanoprobe could specifically image $\mathrm{H}_{2} \mathrm{O}_{2}$ in cancer cells in an acidic microenvironment.

To quantitatively examine that the GC-NABP nanoprobe could promote cellular uptake in an acidic $\mathrm{pH}$ environment, flow cytometric analysis was performed. The fluorescence intensity was found to be directly related to the amount of nanoprobe internalized. As shown in Fig. 3j, the nanoprobe had a greater uptake at $\mathrm{pH} 6.5$ compared with that at $\mathrm{pH}$ 7.4. This result is consistent with the fluorescence imaging studies, confirming that the transition from a negative to positive surface charge indeed facilitated the cellular uptake of the nanoprobe.

The subcellular localization of the GC-NABP nanoprobe was examined using LysoTracker Red as the co-localization reagent. As shown in Fig. 4, the green fluorescence of GC-NABP treated with $\mathrm{H}_{2} \mathrm{O}_{2}$ at physiological temperature $\left(37^{\circ} \mathrm{C}\right)$ overlapped well with the red fluorescence of LysoTracker Red, confirming that the nanoprobes entered the endosomes after cellular internalization. When the incubation temperature was decreased to $4{ }^{\circ} \mathrm{C}$, at which endocytic processes were arrested, the amount of internalized nanoprobes was extremely low, as shown by the weak fluorescence (Fig. S15†). This result suggests that the cellular uptake of the GC-NABP nanoprobe involved an endocytosis pathway, which was energy dependent. 
A comparison between TPM and OPM imaging performance of the nanoprobe in HepG2 cells was also demonstrated. As shown in Fig. S16, $\dagger$ compared with OPM, TPM displayed a high signal-to-noise ratio (fluorescence pixel intensity/background pixel intensity) and high resolution. The good biocompatibility, efficient cellular uptake and strong two-photon fluorescence reveal that the GC-NABP nanoprobe can be used as an excellent two-photon probe for targeted bioimaging of $\mathrm{H}_{2} \mathrm{O}_{2}$ at acidic $\mathrm{pH}$.

\section{Targeted imaging of hydrogen peroxide in tissues under acidic microenvironment}

Another advantage of two-photon probes is the capability of imaging deep inside a tissue. ${ }^{49-52}$ For in vivo bioimaging applications, an exact knowledge about the maximum tissue penetration depth of the nanoprobe was required. Targeted imaging of $\mathrm{H}_{2} \mathrm{O}_{2}$ was also assessed in acidic tissues. TPM images of a slice incubated at pH 7.4 (Fig. 5b) revealed weak fluorescence, and negligible fluorescence was observed at depth of $100 \mu \mathrm{m}$, whereas strong fluorescence was observed for the slice after treatment at pH 6.5 and the penetration depth reached $120 \mu \mathrm{m}$ (Fig. 5d). The results further confirmed the facilitated cellular uptake of the GC-NABP nanoprobe at tumorous $\mathrm{pH}$ and the enhanced visualization of $\mathrm{H}_{2} \mathrm{O}_{2}$ in tumor tissues.

\section{Targeted imaging of hydrogen peroxide in tumor-bearing living mouse model}

Before the investigation into the targeted imaging of $\mathrm{H}_{2} \mathrm{O}_{2}$ in a tumor-bearing living mouse model, we evaluated the blood clearance kinetics and tumor-targeting ability of the GC-NABP nanoprobe in living mice. We labelled GC-NABP with a nearinfrared fluorescent dye, Cy5.5, to prepare $\mathrm{GC}-\mathrm{NH}_{2}-\mathrm{NABP}-$ Cy5.5. GC-NABP-Cy5.5 had a similar diameter to the GC-NABP nanoprobe of about $100 \mathrm{~nm}$, and retained the capability of
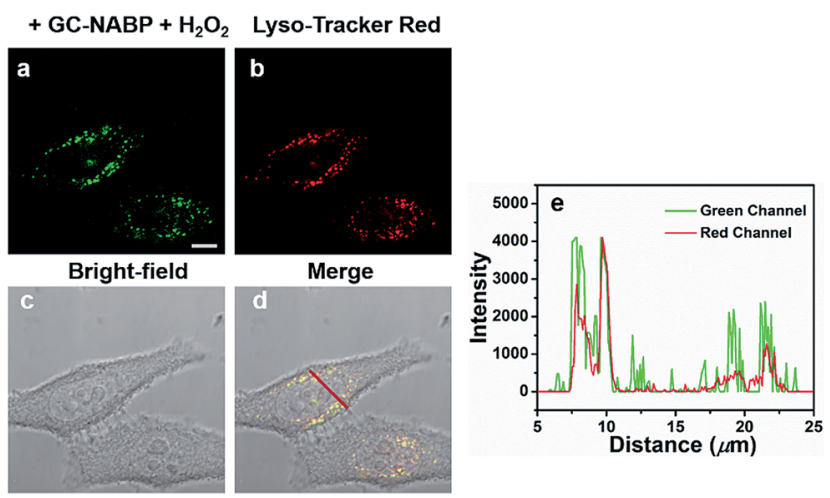

Fig. 4 Intracellular localization of GC-NABP nanoprobes in HepG2 cells. HepG2 cells were incubated with GC-NABP nanoprobes at $37^{\circ} \mathrm{C}$ for $4 \mathrm{~h}$, and then with $200 \mu \mathrm{M} \mathrm{H}_{2} \mathrm{O}_{2}$ for another $1 \mathrm{~h}$. The endosomes were stained with $1 \mu \mathrm{M}$ LysoTracker Red for $10 \mathrm{~min}$. Images of HepG2 cells collected from (a) green channel $\left(\lambda_{\mathrm{ex}}=488 \mathrm{~nm}, \lambda_{\mathrm{em}}=500-550\right.$ $\mathrm{nm}$ ) and (b) red channel ( $\left.\lambda_{\mathrm{ex}}=561 \mathrm{~nm}, \lambda_{\mathrm{em}}=570-620 \mathrm{~nm}\right)$. (c) Brightfield image of HepG2 cells. (d) Merged image of (a), (b) and (c). (e) Fluorescence intensity of HepG2 cells. Location of cells indicated by red line in (d). Scale bar $=10 \mu \mathrm{m}$.

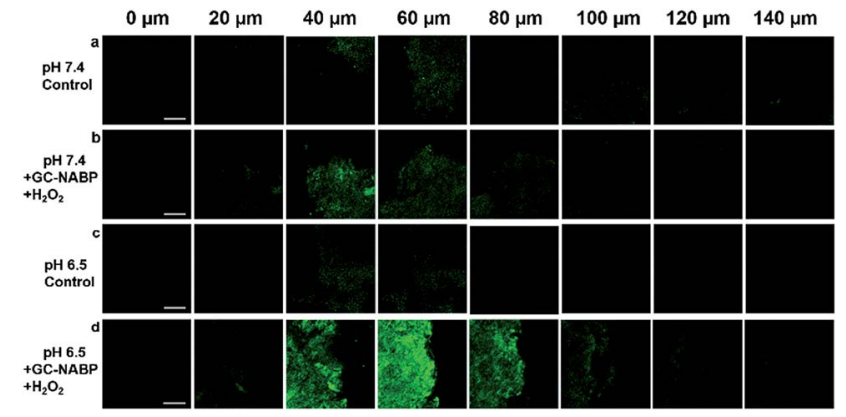

Fig. 5 TPM images of tumor tissue slices with thickness of $500 \mu \mathrm{m}$ at different depths. Control images of tissue slices treated without the nanoprobe at $\mathrm{pH} 7.4$ (a) and $\mathrm{pH} 6.5$ (c). The tissue slice was incubated with the nanoprobe in medium of $\mathrm{pH} 7.4$ (b) or $\mathrm{pH} 6.5$ (d) for $4 \mathrm{~h}$, and then treated with $\mathrm{H}_{2} \mathrm{O}_{2}$ for another $1 \mathrm{~h}$. Scale bar: $50 \mu \mathrm{m}$.

surface charge conversion at acidic pH (Fig. S17†). The blood clearance kinetics of the nanoprobe was examined by intravenous injection of GC- $\mathrm{NH}_{2}-\mathrm{NABP}-\mathrm{Cy} 5.5$ into healthy mice $(1 \mathrm{mg}$ $\mathrm{mL}^{-1}$ in $200 \mu \mathrm{L}$ PBS buffer, $n=3$ ). The concentration of the nanoprobe in the blood was determined using the Cy5.5 fluorescence intensity. As shown in Fig. 6a, the nanoprobe concentration in the blood decreased to $21.5 \%$ of the injected dose $1 \mathrm{~h}$ after injection and further decreased to $4.2 \%$ after $24 \mathrm{~h}$. To demonstrate the effect of surface charge conversion of the nanoprobe on tumor accumulation (aside from the EPR effect), we prepared a control nanoparticle, GC-OH-NABP-Cy5.5, by blocking the pH-titratable amine groups in $\mathrm{GC}-\mathrm{NH}_{2}-\mathrm{NABP}-$ Cy5.5. GC-OH-NABP-Cy5.5 had a similar size to $\mathrm{GC}-\mathrm{NH}_{2}-$ NABP-Cy5.5 (Fig. S17†). Due to the blocking of amine groups, GC-OH-NABP-Cy5.5 exhibited no surface charge dependence

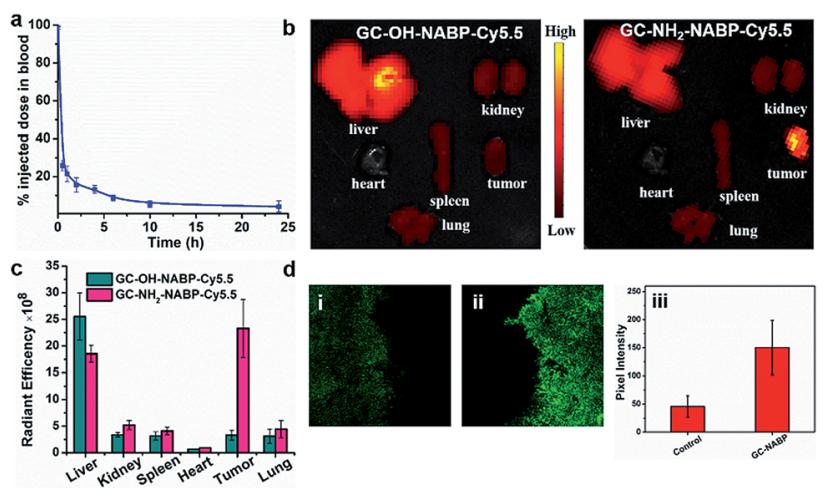

Fig. 6 Blood clearance and targeted $\mathrm{H}_{2} \mathrm{O}_{2}$ imaging in tumor sites of the nanoprobe. (a) The blood clearance kinetics of $\mathrm{GC}-\mathrm{NH}_{2}-\mathrm{NABP}-$ Cy5.5. GC-NH $\mathrm{H}_{2}-\mathrm{NABP}-\mathrm{Cy} 5.5$ nanoparticles were intravenously injected into mice ( $1 \mathrm{mg} \mathrm{mL}^{-1}$ in $200 \mu \mathrm{L}$ PBS buffer, $n=3$ ), and then 5 $\mu \mathrm{L}$ of blood were collected at different time points and diluted in 200 $\mu \mathrm{L}$ PBS for fluorescence measurements. (b) Fluorescent images of tumors and major organs of the 4T1 xenograft tumor-bearing mice $24 \mathrm{~h}$ post-injection of $\mathrm{GC}-\mathrm{OH}-\mathrm{NABP}-\mathrm{Cy} 5.5$ (left) and $\mathrm{GC}-\mathrm{NH}_{2}-$ NABP-Cy5.5 (right). (c) Biodistribution of the nanoparticles quantified from (b). (d) TPM images of tumor tissue slices with thickness of 500 $\mu \mathrm{m}$ from mice intravenously injected by PBS (i) and GC-NABP nanoprobe (ii). (iii) Pixel fluorescence intensity of tissue images. 
on pH. Fig. 6b shows the accumulation of GC-OH-NABP-Cy5.5 and $\mathrm{GC}-\mathrm{NH}_{2}-\mathrm{NABP}-\mathrm{Cy} 5.5$ in tumors and major organs. It was found that $\mathrm{GC}-\mathrm{NH}_{2}-\mathrm{NABP}-\mathrm{Cy} 5.5$ accumulated in tumor at a higher level than GC-OH-NABP-Cy5.5, suggesting that the surface charge conversion of the nanoprobe in acidic $\mathrm{pH}$ promoted tumor accumulation.

Then, we applied the GC-NABP nanoprobe to tumor-targeted $\mathrm{H}_{2} \mathrm{O}_{2}$ imaging in living mice. The GC-NABP nanoprobe was intravenously injected into tumor-bearing mice. Due to the high autofluorescence of the emission at $560 \mathrm{~nm}$, we harvested tumor tissues of mice $24 \mathrm{~h}$ post-injection for two-photon fluorescence imaging. As shown in Fig. 6d, tumor tissues from mice injected with the GC-NABP nanoprobe exhibited brighter fluorescence than the control group injected with $\mathrm{PBS}$, suggesting the accumulation of the nanoprobe and targeted $\mathrm{H}_{2} \mathrm{O}_{2}$ imaging in tumor sites. The targeting ability of the nanoprobe might derive from the enhanced accumulation of the nanoprobe responding to the acidic tumor microenvironment. We expect the design strategy described herein could be extended to construct fluorescent nanoprobes for tumor-targeted imaging of other analytes in living biological systems.

\section{Conclusions}

In conclusion, a pH-responsive, two-photon fluorescent GCNABP nanoprobe was successfully developed for tumor-targeted imaging of intracellular $\mathrm{H}_{2} \mathrm{O}_{2}$ in vivo. Benefiting from the $\mathrm{pH}$ titratable amino groups on GC, this water-soluble and biocompatible nanoprobe had the capability of targeting tumor sites, due to the response to acidic tumor microenvironment of surface charge change from negative to positive promoting cellular uptake. Subsequently, the high levels of $\mathrm{H}_{2} \mathrm{O}_{2}$ in tumor cells triggered the "turn on" fluorescence of the nanoprobe. GCNABP displayed good sensitivity and selectivity to $\mathrm{H}_{2} \mathrm{O}_{2}$. The enhanced cellular uptake and targeted imaging of $\mathrm{H}_{2} \mathrm{O}_{2}$ in living cells and tissues under acidic environment were confirmed using flow cytometry and two-photon fluorescence imaging. The nanoprobe exhibited enhanced accumulation in tumor sites and achieved targeted imaging of $\mathrm{H}_{2} \mathrm{O}_{2}$ in a tumorbearing mouse model. This reported nanoprobe might provide a potential tool to explore the complex role of $\mathrm{H}_{2} \mathrm{O}_{2}$ in tumor sites.

\section{Conflicts of interest}

There are no conflicts to declare.

\section{Acknowledgements}

This work was financially supported by the National Natural Science Foundation of China (21804068, 21890744).

\section{Notes and references}

1 C. C. Winterbourn, Nat. Chem. Biol., 2008, 4, 278-286.

2 S. G. Rhee, Science, 2006, 312, 1882-1883.

3 T. Finke, Curr. Opin. Cell Biol., 2003, 15, 247-254.
4 S. Kawanishi, Y. Hiraku, S. Pinlaor and N. Ma, Biol. Chem., 2006, 387, 365-372.

5 G. Y. Liou and P. Storz, Free Radical Res., 2010, 44, 479-496.

6 D. Trachootham, J. Alexandre and P. Huang, Nat. Rev. Drug Discovery, 2009, 8, 579-591.

7 T. P. Szatrowski and C. F. Nathan, Cancer Res., 1991, 51, 794798.

8 Y. Cheng, J. Dai, C. Sun, R. Liu, T. Zhai, X. Lou and F. Xia, Angew. Chem., Int. Ed., 2018, 57, 3123-3127.

9 B. C. Dickinson, C. Huynh and C. J. Chang, J. Am. Chem. Soc., 2010, 132, 5906-5915.

10 Z. Miao, M. Ye, X. Ye, Y. Wang, H. Zhang, C. Li and Z. Liu, Chem. Sci., 2018, 9, 6035-6040.

11 Z. Miao, H. Jiang, Z. Li, C. Zhong, W. Zhang and Z. Liu, Chem. Sci., 2017, 8, 4533-4538.

12 M. Yang, J. Fan, J. Zhang, J. Du and X. Peng, Chem. Sci., 2018, 9, 6758-6764.

13 W. Zhang, W. Liu, P. Li, F. Huang, H. Wang and B. Tang, Anal. Chem., 2015, 87, 9825-9828.

14 Y. Li, X. Xie, X. Yang, M. Li, X. Jiao, Y. Sun, X. Wang and B. Tang, Chem. Sci., 2017, 8, 4006-4011.

15 D. Cheng, W. Xu, L. Yuan and X. B. Zhang, Anal. Chem., 2017, 89, 7693-7700.

16 Q. Xu, C. H. Heo, G. Kim, H. W. Lee, H. M. Kim and J. Yoon, Angew. Chem., Int. Ed., 2015, 54, 4890-4894.

17 H. W. Kim and B. R. Cho, Chem. Rev., 2015, 115, 5014-5055.

18 Y. L. Pak, S. J. Park, D. Wu, B. H. Cheon, H. M. Kim, J. Bouffard and J. Yoon, Angew. Chem., Int. Ed., 2018, 57, 1567-1571.

19 Y. L. Pak, S. J. Park, G. Song, Y. Yim, H. Kang, H. M. Kim, J. Bouffard and J. Yoon, Anal. Chem., 2018, 90, 12937-12943.

20 W. Zhang, P. Li, F. Yang, X. Hu, C. Sun, W. Zhang, D. Chen and B. Tang, J. Am. Chem. Soc., 2013, 135, 14956-14959.

21 X. Jiao, Y. Xiao, Y. Li, M. Liang, X. Xie, X. Wang and B. Tang, Anal. Chem., 2018, 90, 7510-7516.

22 B. Dong, X. Song, X. Kong, C. Wang, Y. Tang, Y. Liu and W. Lin, Adv. Mater., 2016, 28, 8755-8759.

23 C. Li, R. Pan, P. Li, Q. Guan, J. Ao, K. Wang, L. Xu, X. Liang, X. Jin, C. Zhang and X. Zhu, Anal. Chem., 2017, 89, 59665975.

24 X. L. Hao, Z. J. Guo, C. Zhang and A. M. Ren, Phys. Chem. Chem. Phys., 2019, 21, 281-291.

25 N. Li, J. Huang, Q. Wang, Y. Gu and P. Wang, Sens. Actuators, $B, 2018,254,411-416$.

26 Q. Chen, C. Liang, X. Sun, J. Chen, Z. Yang, H. Zhao, L. Feng and Z. Liu, Proc. Natl. Acad. Sci. U. S. A., 2017, 14, 5343-5348.

27 R. M. Zaguilan, E. A. Seftor, R. E. B. Seftor, Y. W. Chu, R. J. Gillies and M. J. C. Hendrix, Clin. Exp. Metastasis, 1996, 14, 176-186.

28 R. J. Gillies, N. Raghunand, G. S. Karczmar and Z. M. Bhujwalla, J Magn Reson Imaging, 2002, 16, 430-450.

29 P. Vaupel, F. Kallinowski and P. Okunieff, Cancer Res., 1989, 49, 6449-6465.

30 R. K. Jain and T. Stylianopoulos, Nat. Rev. Clin. Oncol., 2010, 7, 653-664.

31 C. Guo, S. Xu, A. Arshad and L. Wang, Chem. Commun., 2018, 54, 9853-9856. 
32 S. Huang, S. Peng, Y. Li, J. Cui, H. Chen and L. Wang, Nano Res., 2015, 8, 1932-1943.

33 J. Xu, W. Han, Z. Cheng, P. Yang, H. Bi, D. Yang, N. Niu, F. He, S. Gai and J. Lin, Chem. Sci., 2018, 9, 3233-3234.

34 X. Xu, J. Wu, Y. Liu, P. E. Saw, W. Tao, M. Yu, H. Zope, M. Si, A. Victorious, J. Rasmussen, D. Ayyash, O. C. Farokhzad and J. Shi, ACS Nano, 2017, 11, 2618-2627.

35 X. Xu, P. E. Saw, W. Tao, Y. Li, X. Ji, M. Yu, M. Mahmoudi, J. Rasmussen, D. Ayyash, Y. Zhou, O. C. Farokhzad and J. Shi, Nano Lett., 2017, 17, 4427-4435.

36 H. J. Li, J. Z. Du, J. Liu, X. J. Du, S. Shen, Y. H. Zhu, X. Wang, X. Ye, S. Nie and J. Wang, ACS Nano, 2016, 10, 6573-6761.

37 H. J. Li, J. Z. Du, X. J. Du, C. F. Xu, C. Y. Sun, H. X. Wang, Z. T. Cao, X. Z. Yang, Y. H. Zhu, S. Nie and J. Wang, Proc. Natl. Acad. Sci. U. S. A., 2016, 113, 4164-4169.

38 A. H. Ranneh, H. Takemoto, S. Sakuma, A. Awaad, T. Nomoto, Y. Mochida, M. Matsui, K. Tomoda, M. Naito and N. Nishiyama, Angew. Chem., Int. Ed., 2018, 130, 51515155.

39 X. Bai, S. Xu and L. Wang, Anal. Chem., 2018, 90, 3270-3275.

40 L. Yan, S. H. Crayton, J. P. Thawani, A. Amirshaghaghi, A. Tsourkas and Z. Cheng, Small, 2015, 11, 4870-4874.

41 S. H. Crayton and A. Tsourkas, ACS Nano, 2011, 5, 95929601.

42 K. Nwe, C. H. Huang and A. Tsourkas, J. Med. Chem., 2013, 56, 7862-7869.
43 J. Y. Yhee, S. Jeon, H. Y. Yoon, M. K. Shim, H. Ko, J. Min, J. H. Na, H. Chang, H. Han, J. H. Kim, M. Suh, H. Lee, J. H. Park, K. Kim and I. C. Kwon, J. Controlled Release, 2017, 267, 223-231.

44 L. Meng, W. Huang, D. Wang, X. Huang, X. Zhu and D. Yan, Biomacromolecules, 2013, 14, 2601-2610.

45 A. R. Lippert, G. C. V. D. Bittner and C. J. Chang, Acc. Chem. Res., 2011, 44, 793-804.

46 C. G. Lux, S. Joshi-Barr, T. Nguyen, E. Mahmoud, E. Schopf, N. Fomina and A. Almutairi, J. Am. Chem. Soc., 2012, 134, 15758-15764.

47 Z. Deng, Y. Qian, Y. Yu, G. Liu, J. Hu, G. Zhang and S. Liu, J. Am. Chem. Soc., 2016, 138, 10452-10466.

48 A. Shrestha and P. H. Park, Life Sci., 2016, 148, 71-79.

49 P. Wang, C. Zhang, H. W. Liu, M. Xiong, S. Y. Yin, Y. Yang, X. X. Hu, X. Yin, X. B. Zhang and W. H. Tan, Chem. Sci., 2017, 8, 8214-8220.

50 P. Wang, F. Zhou, C. Zhang, S. Y. Yin, L. Teng, L. Chen, X. X. Hu, H. W. Liu, X. Yin and X. B. Zhang, Chem. Sci., 2018, 9, 8402-8408.

51 C. Yang, X. Yin, S. Y. Huan, L. Chen, X. X. Hu, M. Y. Xiong, K. Chen and X. B. Zhang, Anal. Chem., 2018, 90, 3118-3123.

52 S. Xu, H. W. Liu, X. X. Hu, S. Y. Huan, J. Zhang, Y. C. Liu, L. Yuan, F. L. Qu, X. B. Zhang and W. Tan, Anal. Chem., 2017, 89, 7641-7648. 